\title{
Melacak Landasan Hukum Pengelolaan Aset Tanah Negara melalui Konsep Bank Tanah
}

\author{
Fatimah Al Zahra \\ (Fakultas Hukum Universitas Brawijaya Jl. M.T. Haryono 169 Malang, Email: \\ iza.fhub@gmail.com)
}

\begin{abstract}
Abstrak:
Kebutuhan akan pembangunan fisik semakin meningkat seiring dengan bertambahnya jumlah penduduk. Problematika penyediaan tanah untuk pembangunan terjadi karena adanya pergeseran makna dan nilai tanah, sebagai akibat dari berkembangnya ideologi ekonomi kapitalis. Rakyat cenderung tidak mau melepaskan tanahnya kepada pemerintah untuk tujuan pembangunan dengan dalih bahwa besaran nilai ganti kerugian yang ditetapkan atas tanah terlalu rendah dan tidak adil. Oleh karena itu, perlu dilakukan revisi kebijakan dalam aspek pertanahan yang mengarahkan pada mekanisme pengelolaan aset tanah negara terintegrasi yang dapat mengakomodasi keinginan semua pihak, sehingga dapat menjamin terciptanya keadilan sosial (al-'Adalah al-Ijtima'iyyah). Penerapan konsep bank tanah sebagai sarana pengelolaan aset tanah negara dapat menjadi solusi dalam mengatasi krisis tanah untuk pembangunan yang terjadi saat ini. Konsep bank tanah yang memperoleh tanah melalui mekanisme jual beli, tukar menukar, hibah maupun lelang akan memenuhi rasa keadilan yang diidam-idamkan oleh rakyat. Sebelum menerapkan konsep bank tanah melalui suatu instrumen hukum, maka konsep tersebut harus terlebih dahulu disesuaikan dengan hukum positif nasional, khususnya dalam sistem hukum agraria. Hal ini perlu dilakukan untuk menghindari terjadinya disharmonisasi antar peraturan perundang-undangan dalam sistem hukum agraria yang saling berhubungan antara satu dan yang lainnya. Artikel ini bertujuan untuk menganalisis landasan hukum mengenai konsep bank tanah sebagai pengelola aset tanah negara yang dapat mewujudkan keadilan sosial (al-'Adalah al-Ijtima'iyyah) bagi seluruh rakyat Indonesia.
\end{abstract}

Kata Kunci:

Landasan Hukum, Konsep Bank Tanah, al-'Adalah al-Ijtima'iyyah, Sistem Hukum

Agraria

al-Lhkam Vol.12 No.2 Desember 2017

DOI 10.19105/al-ihkam.v12i2.1306 


\begin{abstract}
:
The need for physical development is increasing as the increase in population. Any problems in clearing land for development are caused by shifts in land meaning and value, as a consequence of the development of the capitalist economic ideology. The people tend not to relinquish their land to the government for development purposes under the pretext that the amount of compensation paid for land is too low and unfair. Therefore, it is necessary to revise the policy in the land aspect that leads to the integrated state land asset management mechanism that can accommodate the wishes of all parties, so as to ensure the creation of social justice (al-'Adalah alIjtima'iyyah). Implementation of the concept of a land bank as a means of managing state land assets can be a solution in overcoming the land crisis for development that occurs today. The concept of a land bank acquiring land through buying and selling mechanisms, exchange, grants, and auctions will satisfy the sense of justice coveted by the people. Before applying the concept of the land bank through a legal instrument, the concept must be adjusted to national positive law, especially in the legal system of agrarian. This needs to be done to avoid the occurrence of dis-harmonization between laws and regulations in the agrarian legal system that is interconnected between one and the other. This article aims to analyze the legal basis for the concept of the land bank as a manager of state land assets that can realize social justice (al-'Adalah al-Ijtima'iyyah) for Indonesians.
\end{abstract}

Keywords:

The Legal Basis, Concept of the Land Bank, Social Justice, The legal System of Agrarian Land

\title{
Pendahuluan
}

Tanah merupakan kebutuhan dasar manusia yang menjadi modal strategis bagi kehidupan. Di atas tanah, manusia dapat mencari nafkah seperti bertani, berkebun, dan beternak. Di atas tanah pula manusia membangun rumah sebagai tempat bernaung dan membangun berbagai bangunan lainnya untuk perkantoran dan sebagainya. Di dalam tanah juga mengandung berbagai macam kekayaan alam yang dapat dimanfaatkan dalam kehidupan. Kebutuhan akan tanah terus bertambah seiring dengan bertambahnya populasi penduduk. Sebagai tempat bernaung, tanah sangat 
dibutuhkan untuk pembangunan berbagai fasilitas kepentingan umum yang membutuhkan bidang tanah yang sangat luas, sedangkan realitanya tanah-tanah yang dibutuhkan tersebut pada umumnya sudah dimiliki oleh seseorang atau badan hukum dengan dilekati sesuatu hak atas tanah. Kondisi ini menuntut adanya upaya pengadaan tanah untuk keperluan pembangunan tersebut perlu dilakukan dengan sebaik-baiknya dan dilakukan dengan memperhatikan peran tanah dalam kehidupan manusia, serta prinsip penghormatan terhadap Pemegang hak atas tanah yang sah dan tidak menelantarkan kepentingan pribadi pemilik hak atas tanah.

Penelantaran kepentingan pribadi adalah keadaan apabila kebutuhan atau kepentingan yang bersifat pribadi tidak diperhatikan lagi sesuai dengan ketentuan yang berlaku dengan alasan dikalahkan dengan kepentingan umum. Selama ini, Pemerintah menggunakan instrumen pengadaan tanah untuk memperoleh tanah yang dibutuhkan bagi pembangunan fasilitas kepentingan umum. Adapun instrumen pengadaan tanah, sebagaimana diatur dalam UU No. 2/2012 tentang Pengadaan Tanah bagi Pembangunan untuk Kepentingan Umum, dilakukan dengan cara memberikan ganti kerugian yang 'layak \& adil' kepada pemilik tanah yang berhak. Perbedaan persepsi antara Pemerintah dan masyarakat mengenai besaran ganti kerugian yang 'layak \& adil' sering terjadi dalam proses pengadaan tanah. Ganti kerugian yang dirasa 'layak \& adil' menurut Pemerintah belum tentu dirasa 'layak dan adil' menurut masyarakat, begitu pula sebaliknya.

Perbedaan persepsi terkait besaran ganti kerugian yang 'layak dan adil' tersebut akhirnya berujung pada konflik sosial yang sulit untuk diselesaikan dalam waktu singkat, hal ini terjadi karena warga terdampak pengadaan tanah yang merasa keberatan dengan besaran ganti kerugian melakukan upaya hukum melalui Pengadilan Negeri. Adapun batasan waktu pengajuan keberatan oleh warga yaitu selama 14 hari kerja sejak ditandatanganinya Berita Acara hasil musyawarah dan Pengadilan Negeri diberi waktu untuk memutuskan perkara paling lama 30 hari kerja sejak diterimanya pengajuan keberatan, hal ini sebagaimana telah diatur dalam Pasal 73 Peraturan Presiden No. 71/2012 tentang Penyelenggaraan Pengadaan Tanah Bagi Pembangunan untuk Kepentingan Umum. 
Revisi kebijakan yang dimaksud perlu diarahkan pada mekanisme penyediaan tanah bagi pembangunan fasilitas kepentingan umum yang dapat mengakomodiir kepentingan Pemerintah dan masyarakat pemilik tanah secara bersamaan sehingga dapat menjamin terpenuhinya nilai-nilai keadilan bagi rakyat. Kebijakan terhadap penerapan konsep bank tanah di Indonesia dapat menjadi solusi atas kompleksitas permasalahan dalam pengadaan tanah yang dihadapi saat ini. Dalam menganalisis aktualisasi nilainilai keadilan sosial dalam praktik bank tanah, penulis menggunakan teori keadilan yang dianggap relevan, yakni teori keadilan sosial ( $\mathrm{Al}$ 'Adalah al-Ijtima'iyyah) dari Sayyid Qutb. Teori tersebutlah yang akan menjadi pisau analisis dalam artikel ini.

Konsep bank tanah telah digunakan di beberapa negara sebagai salah satu mekanisme untuk menjamin ketersediaan tanah bagi pembangunan, di antaranya negara Belanda, Colombo, dan Korea Selatan. Penyediaan tanah di Belanda adalah praktek konsolidasi tanah dan land readjustment yang dilakukan secara bersama-sama dengan praktek instrumen bank tanah. Praktek bank tanah dibutuhkan dalam pelaksanaan konsolidasi tanah guna mempercepat pelaksanaan dan mempermudah proses akuisisi tanah. Lembaga yang berwenang bersifat ad hoc dan merupakan dewan nasional yang terdiri dari beberapa kementerian atau lembaga yang menjalankan tupoksi masing-masing dalam satu rencana pembangunan kawasan yang disepakati bersama. Kelembagaan ini bersifat non-profit yang tidak ditujukan untuk mencari keuntungan. Peruntukan penggunaannya adalah peningkatan kinerja lahan pertanian, restorasi sungai, dan penggantian lingkungan yang rusak/ penghijauan. ${ }^{1}$ Untuk menerapkan konsep bank tanah di Indonesia, maka Pemerintah harus terlebih dahulu menyusun instrumen hukum yang mengatur bank tanah sebagai legal standing yang memayungi penyelenggaraan bank tanah di Indonesia.

Pengaturan mengenai konsep bank tanah harus mencakup berbagai aspek yang berkaitan dengan penyelenggaraan bank tanah di Indonesia. Jika pengaturannya yang berupa produk hukum sudah

1Ranity Ganindha, “Urgensi Pembentukan Kelembagaan Bank Tanah Sebagai Alternatif Penyediaan Tanah Bagi Masyarakat Untuk Kepentingan Umum", Jurnal Arena Hukum. Vol. 09, No. 03 (Desember, 2016), 456-457 
dibentuk, selanjutnya Pemerintah dapat segera membentuk institusi bank tanah di Indonesia. Sebelum menerapkan konsep bank tanah melalui suatu instrumen hukum, maka konsep tersebut harus terlebih dahulu disesuaikan dengan hukum positif nasional, khususnya yang berkaitan dengan aspek keagrariaan. Hal ini perlu dilakukan untuk menghindari terjadinya disharmonisasi antar peraturan perundangundangan dalam sistem hukum agraria yang saling berhubungan antara satu dan yang lainnya.

Berangkat dari uraian tersebut di atas, maka dapat ditarik suatu permasalahan yang akan dianalisis oleh penulis dalam artikel ini, yakni bagaimana landasan hukum pengelolaan aset tanah negara melalui konsep bank tanah dalam sistem hukum agraria nasional? Dengan menggunakan metode penelitian hukum normatif, penelitian ini bertujuan untuk menemukan jawaban atas permasalahan tersebut. Adapun metode pendekatan yang digunakan dalam penelitian ini adalah pendekatan perundang-undangan (statute approach), pendekatan konseptual (conceptual approach), dan pendekatan perbandingan (comparative approach).

\section{Konsep Bank Tanah secara Umum}

Bank tanah berasal dari 2 (dua) istilah, yaitu land banking dan land banks. Land banking secara umum dapat diterjemahkan ke dalam bahasa lndonesia menjadi "perbankan tanah", yang digunakan untuk menerangkan kegiatan yang berhubungan dengan bank tanah. Sedangkan istilah land banks digunakan untuk menggambarkan adanya lembaga atau kerja sama antar lembaga yang berkegiatan di bidang pengadaan tanah. Istilah bank tanah sendiri mengandung pengertian sebagai: "Land banks are governmental or nonprofit entities that assemble, temporarily manage, and dispose of vacant land" 2 atau "Land banks are public authorities that focus exclusively on land banking activities". 3 Selanjutnya Jack Damen mendefinisikan bahwa "Land banking is the structural acquisition and temporary management of land in rural areas by an impartial State agency, with the purpose to redistribute

2Laura Schwarz, "The Neighborhood Stabilization Program: Land Banking and Rental Housing as Opportunities for Innovation", Journal of Affordable Housing $\mathcal{E}$ Community Development Law, Vol. 19, No.1 (Fall, 2009),. 51

${ }^{3}$ Frank S. Alexander, Land Banking as Metropolitan Policy (Blueprint for American Prosperity), USA: Metropolitan Policy Program at Brookings, (2008),. 3 
and/or lease out this land with a view to improve the agricultural structure and/or to relocate the land for other purposes with a general public interest." 4

Berdasarkan beberapa pengertian yang dipaparkan di atas, maka dapat disimpulkan bahwa bank tanah merupakan suatu kebijakan pertanahan yang mana negara melalui lembaga pemerintahan atau lembaga independen yang ditunjuk oleh Pemerintah, berwenang untuk (1) melakukan akuisisi terhadap tanah terlantar atau bermasalah, tanah yang belum dikembangkan dan tanah yang dianggap memiliki potensi untuk pengembangan; (2) mengelola dan mengaturnya sementara waktu; kemudian (3) mendistribusikannya kembali untuk kepentingan umum sesuai dengan program pemerintah, baik program jangka pendek maupun jangka panjang. Secara umum, skema peralihan hak atas tanah dalam konsep bank tanah dapat dilihat dalam bagan 1 di bawah ini. ${ }^{5}$

\section{Bagan 1. Konsep Bank Tanah}

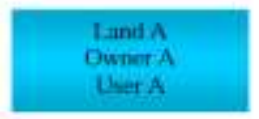

Old-Previous Situation

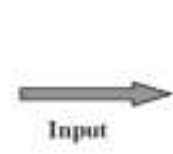

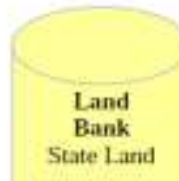

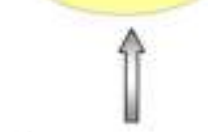

Management

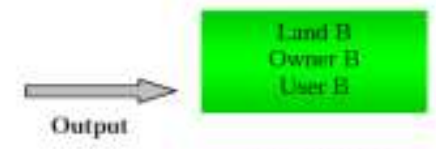

New situation

Sumber: Bahan hukum sekunder, diolah. Mei 2017.

Menurut Bernhard Limbong, berdasarkan konsepsi dan praktik bank tanah di sejumlah negara, maka penerapan bank tanah dapat dibagi ke dalam 3 (tiga) jenis, antara lain: ${ }^{6}$

4Jack Damen, "Land Banking in the Netherlands in the Context of Land Consolidation", $07 \quad$ March 2004: http://www.fao.org/fileadmin/user_upload/Europe/documents/Events_2004/Lan d2004/Netherlands_paper.pdf (diakses tanggal 05 Mei 2017)

5 Dragana Milicevic, "Review of Existing Land Funds in European Countries", Journal of Geonauka, Vol. 2, No. 1 (Maret, 2014), 31-42

${ }^{6}$ Bernhard Limbong, Bank Tanah, (Jakarta: Margaretha Pustaka, 2013), vi-vii 
1. Bank Tanah Umum Publik (General Land Banking) yang ditujukan untuk kepentingan pembangunan di masa depan yang bersifat umum, berskala luas, dan non-profit, seperti untuk pengendalian bencana alam, pertahanan negara, peremajaan dan pengembangan kota, rekonstruksi dan relokasi warga, perluasan areal pertanian, transmigrasi, dan pelaksanaan reforma agraria;

2. Bank Tanah Khusus Publik (Special Land Banking) dengan skala lebih kecil dan berorientasi pada public service sekaligus profit oriented, seperti infrastruktur transportasi darat, laut, udara, perkebunan, kawasan industri, dan perumahan murah bersubsidi. Karena bersifat publik, maka status kelembagaan kedua bank tanah tersebut bisa berbentuk bank tanah departemen atau lembaga negara, bank tanah pemerintah daerah/ pemerintah kota, dan bank tanah BUMN/BUMD;

3. Bank Tanah Swasta yang profit oriented, terutama bank tanah untuk mendukung kegiatan investasi yang terus membaik, seperti bank tanah untuk pengembang, kawasan industri, pusat perdagangan, dan perkebunan.

Ketiga alternatif jenis bank tanah sebagaimana tersebut di atas harus disesuaikan dengan tujuan yang hendak dicapai oleh pemerintah. Adapun fungsi dari bank tanah sangat banyak, konsep bank tanah sebagai alternatif pengadaan tanah dapat mempunyai beberapa fungsi, yaitu: ${ }^{7}$

1. Sebagai Penghimpun Tanah (Land Keeper)

Sebagai penghimpun tanah, lembaga bank tanah melakukan inventarisasi terhadap tanah-tanah yang dijadikan objek pengelolaan bank tanah. Selain kegiatan penghimpunan tanah, bank tanah juga mengumpulkan dan menyediakan data pertanahan yang lengkap, akurat, terpadu dan aktual;

2. Sebagai Pengaman Tanah (Land Warantee)

Bank tanah dalam melaksanakan kegiatannya mengacu kepada rencana tata ruang untuk mengamankan penyediaan, peruntukan dan pemanfaatan tanah yang sudah ditetapkan berdasarkan rencana tata guna tanah yang merupakan bagian terintegrasi dari rencana tata ruang yang ada;

\footnotetext{
7 Ibid., vii.
} 
3. Sebagai Pengendali Penguasaan Tanah (Land Purchaser)

Melalui kegiatan bank tanah yang mengacu pada rencana tata ruang yang sudah ditetapkan, maka implementasinya dimulai dari perencanaan, pemanfaatan dan pengendalian. Melalui rencana tata ruang, bank tanah dapat melakukan pengendalian terhadap penguasaan tanah sehingga penguasaan tanah tidak terpusat pada kelompok masyarakat tertentu;

4. Sebagai Pengelola Tanah (Land Manager)

Bank tanah sebagai kegiatan pengelolaan tanah secara konseptual harus memuat kebijakan dan strategi optimalisasi pemanfaatan dan penggunaan tanah, sehingga eksistensi bank tanah harus mampu mengarahkan pengembangan penggunaan tanah;

5. Sebagai Penilai Tanah (Land Appraisal)

Melalui bank tanah diharapkan harga dan nilai tanah dapat ditetapkan dan dikendalikan sesuai dengan peraturan perundangundangan yang berlaku;

6. Sebagai Penyalur Tanah (Land Distributor)

Kegiatan bank tanah meliputi kegiatan pembebasan tanah, pematangan tanah, kemudian pendistribusian tanah sesuai dengan peruntukan dan penggunaannya.

Konsep bank tanah sudah dikenal dan diterapkan di beberapa negara Eropa dan Amerika Serikat sejak abad ke-20. Belanda memiliki konsep bank tanah yang menonjol dengan regulasi lengkap. Implementasi konsep bank tanah di Belanda dapat ditinjau dari 4 (empat) indikator, yaitu: (1) regulasi, (2) jenis, (3) pihak-pihak yang menyelenggarakan, dan (4) mekanisme penyelenggaraan.

1. Regulasi Bank Tanah

Belanda mengatur mengenai konsep bank tanah di dalam beberapa regulasi di antaranya:8 (a) Undang-Undang Konsolidasi Tanah (Land Consolidation Act), 1954, (b) Undang-Undang Pembangunan Daerah Pedesaan (The rural area development Act), 1985, dan (c) Undang-Undang Penataan Ruang Daerah Pedesaan (Act on Spatial Structuring of the Rural Areas), 2005.

2. Jenis Bank Tanah 8 Dragana Milicevic, "Review of Existing Land Funds in European Countries”, Journal
of Geonauka, Vol. 02, No. 01 (Maret, 2014), 31-42 
Di Belanda terdapat 2 (dua) bank tanah yang secara vertikal berada di bawah naungan 2 (dua) kementerian yang berbeda. Kedua bank tanah tersebut merupakan bank tanah publik, sehingga sumber pembiayaannya murni berasal dari anggaran pemerintah tanpa ada campur tangan dari pihak swasta. Bank tanah yang pertama disebut State Domain Services (Domeinen) yang didirikan pada tahun 1841 di bawah naungan Menteri Keuangan. Pengelolaan bank tanah ini didesentralisasikan dengan kantor wilayah yang tersebar di seluruh wilayah Belanda. Saat ini, bank tanah ini mengelola lahan pertanian seluas 80.000 ha dengan tugas utamanya sebagai berikut: (a) pengembangan kebijakan pertanahan pemerintah, (b) pengelolaan tanah yang dimiliki oleh pemerintah, (c) penjualan tanah pemerintah.

Lalu pada pertengahan abad ke-20 juga didirikan instansi pengelolaan tanah pemerintah kedua bernama Wieringermeer atau yang kemudian disebut Service of IJssellake Polders (RIJP). Instansi ini didirikan di lingkungan Kementerian Transportasi dan Air dengan tujuan mengelola tanah-tanah "baru", yaitu tanah-tanah kering. Salah satu danau terluas di dunia yang bernama Flevopolder dikelola oleh instansi ini dan masih dalam tahap pengembangan. ${ }^{9}$

3. Pihak-Pihak dalam Bank Tanah

Di Belanda terdapat 2 (dua) bank tanah yang keduanya merupakan bank tanah publik. Sehingga dapat dipastikan tidak ada unsur swasta dalam tata kelola bank tanah di Belanda dan semua sumber pembiayaan untuk penyelenggaraan bank tanah hanya berasal dari anggaran pemerintah.

4. Mekanisme Penyelenggaraan Bank Tanah

Mekanisme penyelenggaraan bank tanah di Belanda terdiri dari 3 (tiga) tahapan, yaitu tahap pengumpulan tanah, tahap pengelolaan tanah dan tahap distribusi tanah. Program Land Company Dienst Landelijk Gebied sebagai pedoman pelaksanaan bank tanah di Belanda, membedakan metode pengumpulan dan pengelolaan hingga distribusi tanah ke dalam beberapa kategori, antara lain:10

\footnotetext{
${ }^{9}$ Ibid.

10 Sungkana, "Mengenal Bank Tanah/ Land Banking Sebagai Alternatif Manajemen Pertanahan", 
a. Tahapan pengumpulan tanah oleh Exchange Land Bank, di mana tanah pertanian dibeli untuk disimpan sementara waktu, sampai terjadi pertukaran. Hal ini ditujukan untuk mengembangkan struktur pertanian hingga ke pedesaan.

b. Tahap pengelolaan tanah oleh Financial Instrument, di mana bank tanah menyewakan tanah untuk sementara atau permanen kepada petani atau organisasi lain untuk memelihara tata ruang. Kategori ini sudah tidak banyak digunakan di sektor pertanian.

c. Tahap distribusi tanah atau Land Bank as Developer, di mana bentuk kegiatan mengubah fungsi dari suatu wilayah sebagai sumber pendapatan. Fungsi tanah digunakan untuk kebutuhan perumahan (real estate), pengembangan kota, sumber daya alam, rekreasi dan sebagainya. Biasanya kategori ini digunakan dalam lingkungan perkotaan besar dan dilakukan oleh sektor privat sebagai bentuk investasi, dengan mengubah wilayah pertanian menjadi wilayah perindustrian.

\section{Konsep Keadilan Sosial Dalam Penyelenggaraan Bank Tanah}

Gustav Radbruch mengemukakan bahwa tujuan hukum harus dipahami sebagai dasar sekaligus pengikat dalam pembentukan perundang-undangan. Terdapat 3 (tiga) nilai dasar dari hukum yang kemudian dikenal dengan cita hukum, yang mana hukum harus memenuhi nilai-nilai dasar tersebut, yaitu: keadilan, kegunaan (zweckmaszigkeit), dan kepastian hukum.11

Hukum yang baik harus memberikan keadilan, karena ruh dari hukum adalah keadilan, sebagaimana yang disebutkan dalam penggalan Al Qur'an yakni Q.S. al-Nisa' 4:58 berbunyi wa idzâa hakamtum bayn al-nâs an tahkumûu bi al-'adl, yang dapat diartikan "Dan apabila kamu menetapkan hukum di antara manusia supaya kamu menetapkan dengan adil". Ayat ini menjelaskan adanya amanah yang dipikul oleh si pembuat hukum untuk memberikan jaminan keadilan bagi siapapun.

https://www.djkn.kemenkeu.go.id/2013/artikel/mengenal-bank-tanahlandbanking-sebagai-alternatif-manajemen-pertanahan (diakses tanggal 15 Mei 2017)

11 Emsi Warasih, Pranata Hukum Sebuah Telaah Sosiologis, (Semarang: PT. Suryandaru Utama, 2005), 44 
Suatu peraturan perundang-undangan yang baik harus bisa menciptakan keadilan bagi berbagai pihak, menciptakan posisi yang proporsional dan tidak timpang sebelah. Pihak inti yang sangat berperan dalam penyelenggaraan bank tanah publik ini adalah pemerintah dan masyarakat. Sebagaimana dipraktekkan di beberapa negara lain, dalam penyelenggaraan bank tanah publik telah terjadi perbuatan hukum berupa peralihan aset berupa hak atas tanah yang dapat berupa jual-beli, tukar menukar, maupun hibah antara pemerintah dan masyarakat. Suatu hubungan hukum yang adil dapat diciptakan melalui proses dan prosedur yang benar, transparan, dan memberikan jaminan akuntabilitas. Meski semua orang menghendaki terwujudnya keadilan, namun tidak kesemuanya memahami dan mengerti makna keadilan.

Teori Keadilan sosial menurut Islam dicetuskan oleh Sayyid Qutb dalam kitabnya yang berjudul Al-'Adalah al-Ijtima'iyyah fi' alIslam (yang kemudian dialihbahasakan dengan buku yang berjudul Keadilan Sosial dalam Islam). Sayyid Qutb berpandangan bahwa keadilan sosial dalam kehidupan tidak mungkin dapat ditegakkan bila setiap anggota masyarakatnya ingin menikmati kebebasan mutlak tanpa batas dan tanpa arah tertentu. Kata Quthb, keadaan semacam ini merupakan jaminan bagi hancurnya masyarakat yang pasti pula akan menghancurkan anggota masyarakat itu sendiri. ${ }^{12}$ Dengan artian bahwa kebebasan harus diberikan dalam kehidupan dengan catatan tidak ada kebebasan mutlak tanpa batas. Islam akan memberikan keadilan pada semua segi kehidupan.

Sayyid Quthb mengungkapkan tentang keadilan sosial dalam Islam: "Di sini setiap individu menikmati keadilan yang sama, tidak ada diskriminasi antara mereka yang muncul karena nasab dan kekayaan, karena uang dan pangkat/ jabatan sebagaimana yang ada pada umat di luar Islam, walaupun antara kaum muslimin dan orang-orang non-Islam itu terdapat permusuhan dan kebencian. Sungguh ini merupakan nilai keadilan yang belum pernah dicapai oleh hukum internasional manapun dan juga oleh hukum lokal manapun sampai detik ini"13 Artinya adalah bahwa tidak ada yang dapat mempengaruhi atas tegaknya keadilan, apapun yang

\footnotetext{
12 Sayyid Qutb, Keadilan Sosial dalam Islam, (Bandung: Pustaka, 1984), 79

13 Ibid, 130
} 
mencoba menghalangi keadilan baik harta maupun nasab maupun jabatan adalah tidak benar.

Berkaitan dengan praktik bank tanah, keadilan sosial ini terletak pada persamaan kesempatan dalam kepemilikan tanah bagi seluruh rakyat, khususnya bagi petani-petani yang tidak memiliki tanah garapannya sendiri dan masyarakat berpenghasilan rendah, untuk bisa memiliki tanah melalui redistribusi tanah yang merupakan program unggulan dari bank tanah.

Redistribusi tanah merupakan bagian dari program pembaruan agrarian yang bertujuan untuk memakmurkan para petani di Indonesia. Pasal 4 huruf (g) Ketetapan MPR RI No. IX/MPR/2001 menjelaskan bahwa sumber daya agraria/ sumber daya alam yang meliputi bumi, air, ruang angkasa dan kekayaan alam di dalamnya merupakan kekayaan nasional yang harus dikelola dan dimanfaatkan secara optimal bagi generasi sekarang dan generasi mendatang dalam rangka mewujudkan masyarakat adil dan makmur.

Selain persamaan kesempatan dalam kepemilikan tanah, dalam praktik bank tanah juga akan tercipta suatu persamaan kedudukan dalam arti persamaan hak antara pemerintah dan masyarakat. Misalnya dalam proses perolehan tanah hak milik melalui jual beli, pemerintah sebagai pembeli dan masyarakat sebagai pemilik hak atas tanah diberi hak yang sama untuk merealisasikan keinginannya masing-masing mengenai besaran nilai/harga tanah yang hendak diakuisisi oleh bank tanah, yaitu sama-sama sepakat dengan harga. Jual beli tanah tidak boleh terjadi tanpa adanya kesepakatan dari kedua belah pihak. Pemerintah sebagai otoritas yang berkuasa tidak boleh sewenang-wenang dalam menentukan nilai/harga tanah.

\section{Landasan Hukum Konsep Bank Tanah dalam Sistem Hukum Agraria}

1. Hak Menguasai Negara Sebagai Landasan Konstitusional Bank Tanah

Pasal 33 Ayat (3) Undang-Undang Dasar Tahun 1945 (selanjutnya disebut UUD 1945) menyatakan bahwa bumi, air, dan kekayaan alam yang terkandung di dalamnya dikuasai oleh negara dan dipergunakan untuk sebesar-besarnya kemakmuran rakyat. Frasa "dikuasai oleh negara" haruslah diartikan mencakup makna 
penguasaan oleh negara dalam artian luas yang berasal dari konsepsi kedaulatan rakyat Indonesia atas segala sumber kekayaan berupa "bumi, air, dan kekayaan alam yang terkandung di dalamnya", termasuk pula di dalamnya pengertian kepemilikan publik oleh rakyat secara kolektif atas sumber kekayaan dimaksud. UUD 1945 mengkonstruksikan bahwa rakyat secara kolektiflah yang memberikan mandat kepada negara untuk mengadakan kebijakan (beleid), tindakan pengurusan (bestuursdaad), pengaturan (regelendaad), pengelolaan (beheersdaad), dan pengawasan (toezichthoudensdaad) untuk tujuan sebesar-besarya kemakmuran rakyat.

Dalam Putusan Mahkamah Konstitusi No. Perkara 001-021022/PUU-1/2003 dijabarkan mengenai fungsi pengurusan (bestuursdaad) oleh negara dilakukan oleh pemerintah dengan kewenangannya untuk mengeluarkan dan mencabut fasilitas perizinan (vergunning), lisensi (licentie), dan konsesi (concessie). Fungsi pengaturan oleh negara (regelendaad) dilakukan melalui kewenangan legislasi oleh DPR bersama dengan Pemerintah dan regulasi oleh Pemerintah (eksekutif). Fungsi pengelolaan (beheersdaad) dilakukan melalui mekanisme pemilikan saham (share-holding) dan/atau melalui keterlibatan langsung dalam manajemen Badan Usaha Milik Negara atau Badan Hukum Milik Negara sebagai instrumen kelembagaan melalui mana negara c.q. Pemerintah mendayagunakan penguasaannya atas sumber-sumber kekayaan itu untuk digunakan bagi sebesar-besarnya kemakmuran rakyat. Adapun fungsi pengawasan oleh negara (toezichthoudensdaad) dilakukan oleh negara c.q Pemerintah dalam rangka mengawasi dan mengendalikan agar pelaksanaan penguasaan oleh negara atas cabang produksi yang penting dan/atau yang menguasai hajat hidup orang banyak dimaksud benar-benar dilakukan untuk sebesar-besarya kemakmuran seluruh rakyat.

Konsep "dikuasai oleh negara" dalam Pasal 33 Ayat (3) UUD 1945 kemudian dijabarkan lebih lanjut dalam Pasal 2 Ayat (1) Undang-Undang No. 5 Tahun 1960 tentang Peraturan Dasar PokokPokok Agraria yang lebih dikenal dengan Undang-Undang Pokok Agraria (selanjutnya disebut UUPA) yang menyatakan bahwa negara adalah organisasi kekuasaan seluruh rakyat Indonesia. Arie Sukanti 
Hutagalung dan Markus Gunawan ${ }^{14}$ selanjutnya mengartikan Pasal 2 Ayat (1) UUPA tersebut berisi pernyataan bahwa bangsa Indonesia membentuk Negara Republik Indonesia untuk melindungi segenap tanah air Indonesia dan melaksanakan tujuan bangsa Indonesia untuk memajukan kesejahteraan umum. Lebih lanjut, rumusan Pasal 1 Ayat (1) UUPA menyatakan bahwa seluruh wilayah adalah kesatuan tanah air dari seluruh rakyat Indonesia yang bersatu sebagai bangsa Indonesia. Hal ini berarti bahwa tanah di seluruh wilayah Indonesia adalah hak bersama dari bangsa Indonesia. Hak bangsa mengandung 2 (dua) unsur, yang antara lain:

1. Unsur kepunyaan bersama yang bersifat perdata, tetapi bukan berarti hak kepemilikan dalam arti yuridis, namun tanah bersama dari seluruh rakyat Indonesia yang telah bersatu menjadi bangsa Indonesia.

2. Unsur tugas kewenangan yang bersifat publik, untuk mengatur dan memimpin pengguasaan dan penggunaan tanah yang dipunyai bersama tersebut.

Guna merepresentasikan hak bangsa Indonesia tersebut, tentu penguasaan negara atas tanah termasuk dalam hukum publik yang tidak mungkin dilaksanakan sendiri oleh rakyat. Oleh karena itu, penyelenggaraan penguasaan dilakukan oleh bangsa Indonesia sendiri sebagai pemegang hak dan pengemban amanat yang berada pada tingkatan tertinggi dengan mendelegasikan penguasaan tersebut kepada negara sebagai organisasi kekuasaan seluruh rakyat Indonesia. Untuk melaksanakan tugas penguasaan tersebut, Negara Republik Indonesia mempunyai hubungan hukum dengan tanah di seluruh wilayah Republik Indonesia.

Hubungan hukum antara Negara dengan tanah di seluruh wilayah Republik Indonesia inilah yang dinamakan Hak Menguasai Negara (selanjutnya disebut HMN). HMN adalah sebutan yang diberikan oleh UUPA kepada hubungan hukum konkret antara negara dan tanah di Indonesia, yang dirinci isi dan tujuannya dalam Pasal 2 Ayat (2) dan (3) UUPA (Harsono, 2008). Kendatipun demikian, HMN tidak memberi kewenangan untuk menguasai tanah

\footnotetext{
${ }^{14}$ Arie Sukanti Hutagalung dan Markus Gunawan, Kewenangan Pemerintah di Bidang
} Pertanahan, (Jakarta: Raja Grafindo Persada, 2008). 23 
secara fisik dan menggunakannya seperti hak atas tanah lain secara umum karena sifatnya semata-mata sebagai kewenangan publik. Pengertian "dikuasai" dalam konteks HMN memiliki batasan, yaitu digunakan untuk kemakmuran rakyat Indonesia.

HMN merupakan landasan konstitusional bagi pengaturan bank tanah, yang nantinya akan memberikan kewenangan pada negara (dalam hal ini Pemerintah) untuk dapat menerapkan konsep bank tanah di Indonesia. Eksistensi bank tanah sebagai pengelola aset tanah negara yang terintegrasi merupakan solusi yang ideal atas berbagai permasalahan ketersediaan tanah yang hingga saat ini belum terselesaikan.

\section{Konsep Bank Tanah Ditinjau dari Berbagai Aspek Dalam Sistem Hukum Agraria}

Sistem hukum agraria Indonesia telah memiliki landasan hukum keagrariannya melalui UUPA dan berbagai kebijakan pertanahan terkait. Kebijakan pertanahan yang dimaksud dalam konstitusi nasional adalah mencakup pengaturan berbagai aspek pertanahan yang telah termuat dalam UUPA dan piranti strategis seperti Ketetapan Majelis Pemusyawaratan Rakyat (TAP MPR), Garis Besar Haluan Negara (GBHN), dan peraturan perundang-undangan lain terkait pertanahan. Aspek pertanahan yang menjadi substansi kebijakan pertanahan terdiri dari: ${ }^{15}$

a. Aspek hukum, yaitu kelembagaan yang mengurusi masalah keperdataan tentang tanah. Lembaga yang mengurusi hukum perdata pertanahan ini yaitu Badan Pertanahan Nasional (BPN), yang saat ini berubah menjadi Kementerian Agraria dan Tata Ruang;

b. Aspek tata ruang, yaitu kelembagaan yang menangani masalah penataan ruang bagi pembangunan dan tata kota ataupun desa. Pihak yang menangani tata ruang ini yaitu Pemerintah Daerah.

c. Aspek pajak, yaitu kelembagaan yang berperan dalam mengurusi pajak bagi pertanahan, di antaranya yaitu pajak bumi dan bangunan. Aspek ini merupakan aspek yang memberikan

\footnotetext{
15 Bernhard Limbong, Bank Tanah..., 15
} 
pemasukan bagi Negara. Pada aspek ini lembaga yang berperan yaitu Departemen Keuangan.

Pengaturan bank tanah di Indonesia harus disesuaikan dengan berbagai aspek lain selain ketiga aspek di atas. Hal ini perlu diperhatikan agar tidak terjadi benturan kepentingan atau disharmonisasi aturan antar aspek yang saling berkaitan antara satu dan yang lainnya dalam sistem hukum agraria Indonesia. Praktek bank tanah tidak bisa dijalankankan secara sepihak tanpa ada sinkronisasi program dari berbagai aspek yang saling berhubungan dalam sistem hukum agraria Indonesia.

Adapun keterkaitan pengaturan bank tanah dengan berbagai aspek dalam sistem hukum agraria Indonesia dijelaskan secara rinci dalam pembahasan tersendiri di bawah ini.

\section{A. Bank Tanah Sebagai Bagian dari Pembaruan Agraria}

Kebijakan pertanahan nasional yang dirumuskan dalam Pasal 33 Ayat (3) UUD 1945 didasarkan pada konsep bahwa semua tanah adalah tanah bangsa Indonesia. Pasal 4 huruf (g) Ketetapan MPR RI No. IX/MPR/2001 tentang Pembaruan Agraria dan Pengelolaan Sumber Daya Alam (selanjutnya disebut TAP MPR RI No. IX/MPR/2001) juga menjelaskan bahwa sumber daya agraria/ sumber daya alam yang meliputi bumi, air, ruang angkasa dan kekayaan alam di dalamnya merupakan kekayaan nasional yang harus dikelola dan dimanfaatkan secara optimal bagi generasi sekarang dan generasi mendatang dalam rangka mewujudkan masyarakat adil dan makmur.

TAP MPR RI No. IX/MPR/2001 adalah landasan bagi pembentukan berbagai peraturan perundang-undangan mengenai pembaruan agrarian di Indonesia. Peraturan perundang-undangan mengenai bank tanah dapat dibuat selama menjunjung tinggi prinsip-prinsip pembaruan agraria, yaitu memperhatikan fungsi sosial tanah dan kesejahteraan rakyat, baik untuk generasi sekarang maupun generasi mendatang. Peraturan perundangundangan tersebut harus mampu menjaga keseimbangan antara hak dan kewajiban negara, Pemerintah (baik pusat maupun daerah), dan masyarakatnya. Sebagai bentuk kebijakan pertanahan, peraturan yang telah dibuat oleh pemerintah dapat 
dikaji dan ditambah, sehingga dapat pula ditambahkan pengaturan mengenai bank tanah.

\section{B. Bank Tanah Sebagai Bagian dari Penataan Ruang}

Aspek penentuan tanah-tanah yang dapat diambil alih oleh negara membutuhkan perencanaan dalam bentuk penataan ruang, untuk menentukan tanah mana yang diperlukan, berapa banyak yang perlu diambil, bagian mana yang perlu dimatangkan terlebih dahulu, kemungkinan penggunaannya sementara waktu sebelum disalurkan dan penyaluran tanah untuk keperluan apa, yang sebagian besar tergantung kepada studi kelayakan dalam rencana tata ruang. ${ }^{16}$ Pasal 1 angka 5 Undang-Undang No. 26 Tahun 2007 tentang Penataan Ruang (selanjutnya disebut UU Penataan Ruang) mengartikan penataan ruang sebagai suatu sistem proses perencanaan tata ruang, pemanfaatan ruang, dan pengendalian pemanfaatan ruang. Rangkaian proses yang diawali dengan perencanaan hingga pengendalian merupakan satu kesatuan yang tidak terpisahkan antara yang satu dan yang lain dan harus dilakukan sesuai dengan kaidah penataan ruang.

Penyelenggaraan penataan ruang dilaksanakan secara bersama-sama dan bertingkat oleh pemerintah pusat dan pemerintah daerah, baik provinsi maupun kabupaten/ kota yang pelaksanaan wewenangnya dilakukan dengan tetap menghormati hak yang dimiliki oleh setiap orang. Penyelenggaraan tersebut sejalan dengan terminologi yang digunakan dalam UU Penataan Ruang, yakni penataan ruang wilayah nasional, provinsi, dan kabupaten/ kota.

\section{Bank Tanah sebagai Kebijakan Penanganan Tanah Terlantar}

Peningkatan kebutuhan penduduk akan ruang sebagai akibat dari peningkatan kualitas hidup dapat menyebabkan meningkatnya kebutuhan akan tanah. ${ }^{17}$ Oleh karenanya, baik aspek penguasaan maupun pemanfaatan atas tanah bergantung pada mekanisme pasar dan peraturan perundang-undangan yang

\footnotetext{
16 Maria S.W. Sumarjdono, Kebijakan Pertanahan antara Regulasi dan Implementasi, (Jakarta: Kompas Gramedia, 2001), 20

17 Rusmadi Murad, Administrasi Pertanahan, (Bandung: Mandar Maju, 1997),. 10
} 
berlaku. Pengaturan yang tidak tepat berimplikasi terhadap spekulasi harga. Spekulasi harga tanah yang tidak transparan dalam praktik pasar tanah menciptakan persaingan yang tidak sehat, yang kemudian menghambat kelancaran pembangunan, terutama pembangunan untuk kepentingan umum. Tidak hanya itu, ketimpangan kepemilikan dan penguasaan tidak terhindarkan karena kepemilikannya terkonsentrasi pada segelintir orang bermodal besar. Konsekuensi penelantaran tanah yang dilakukan oleh pemilik tanah mengakibatkan pemerintah sebagai pemilik otoritas memiliki kewenangan untuk menarik kembali dan menjadikan tanah tersebut untuk kemaslahatan sosial. ${ }^{18}$

Pendayagunaan terhadap tanah terlantar dapat berkontribusi secara nyata untuk sebesar-besar kemakmuran masyarakat dalam bentuk terwujudnya transfer kesejahteraan melalui redistribusi tanah. Untuk itu, bank tanah merupakan strategi yang dapat dikembangkan karena manfaatnya akan berimplikasi pada peningkatan kesejahteraan dan kemakmuran rakyat. Sebagaimana yang telah dipraktekkan di Belanda, lembaga bank tanah mengelola aset tanah negara yang tidak produktif menjadi tanah produktif dan bernilai jual.

\section{Bank Tanah sebagai Badan Independen dari Kerja Sama Kelembagaan}

Keterpaduan, sinergi, fokus dan konsistensi merupakan kunci keberhasilan pelaksanaan pembangunan mendatang dalam mewujudkan target pembangunan, yaitu kesejahteraan rakyat yang berkeadilan. Hal ini tidak dapat lagi dilakukan secara terkotak-kotak hanya demi kepentingan pencapaian yang bersifat sektoral (ego sektoral) atau dikotomi pusat daerah yang dapat mendistorsi pencapaian target kesejahteraan rakyat yang berkeadilan. ${ }^{19}$ Untuk mencapai keberhasilan tersebut, Indonesia

\footnotetext{
18 Ridwan, "Management of Abondoned Land in the Perspective of Islamic Law and National Law of Land", Jurnal Al-Ihkam, Vol. 11, No. 1 (Juni, 2016), 19

${ }^{19}$ Kementerian Perencanaan Pembangunan Nasional/ Badan Perencanaan Pembangunan Nasional, Buku Pegangan Perencanaan Pembangunan Daerah 2014Memantapkan Perekonomian Nasional Bagi Peningkatan Kesejahteraan Rakyat yang Berkeadilan, (Jakarta: Kementerian Perencanaan Pembangunan Nasional/ Badan Perencanaan Pembangunan Nasional, 2013), 25
} 
telah memiliki beberapa badan/lembaga yang relevan dengan kegiatan bank tanah, sehingga perlu melakukan kerja sama kelembagaan, badan/lembaga yang dimaksud terdiri dari:

\section{Badan Pertanahan Nasional (BPN)}

Pasal 3 Peraturan Presiden No. 63 Tahun 2013 tentang Badan Pertanahan Nasional Republik Indonesia memberikan kewenangan kepada BPN untuk menyusun norma-norma dan/ atau standardisasi mekanisme ketatalaksanaan, kualitas produk dan kualifikasi sumber daya manusia yang diperlukan. Kendatipun demikian, sebagian kewenangan Pemerintah di bidang pertanahan kini dilaksanakan oleh Pemerintah Daerah, adapun kewenangan yang dimaksud disebutkan dalam Pasal 2 Ayat (l) Keputusan Presiden No. 34 Tahun 2003 tentang Kebijakan Nasional di Bidang Pertanahan (selanjutnya disebut Keppres No. 34 Tahun 2003) antara lain: (a) pemberian ijin lokasi; (b) penyelenggaraan pengadaan tanah untuk kepentingan pembangunan; (c) penyelesaian sengketa tanah garapan; (d) penyelesaian masalah ganti kerugian dan santunan tanah untuk pembangunan; (e) penetapan subyek dan obyek redistribusi tanah, serta ganti kerugian tanah kelebihan maksimum dan tanah absentee; (f) penetapan dan penyelesaian masalah tanah ulayat; (g) pemanfaatan dan penyelesaian masalah tanah ulayat; (g) pemanfaatan dan penyelesaian masalah tanah kosong; dan (h) pemberian ijin membuka tanah; (i) perencanaan penggunaan tanah wilayah kabupaten/ kota. Pendelegasian kewenangan ini sesuai dengan bentuk pemerintahan di Indonesia yang terdesentralisasi sebagai wujud dari otonomi daerah.

2. Badan Kebijaksanaan dan Pengendalian Pembangunan Perumahan dan Pemukiman Nasional (BKP4N)

Pembangunan perumahan dan pemukiman merupakan kegiatan yang bersifat lintas sektoral, yang pelaksanaannya perlu memperhatikan aspek-aspek prasarana dan sarana lingkungan, rencana tata ruang, industri bahan, jasa konstruksi dan rancang bangun, pembiayaan, sumber daya manusia, kemitraan antar pelaku, peraturan perundang-undangan dan aspek penunjang lainnya. Oleh karena itu, BKP4N dibutuhkan mengingat luasnya 
lingkup permasalahan pembangunan perumahan dan pemukiman. Keputusan Presiden No. 63 Tahun 2000 tentang Badan Kebijaksanaan dan Pengendalian Pembangunan Perumahan dan Pemukiman Nasional mengartikan BKP4N sebagai badan nonstruktural yang dipimpin oleh Menteri Pemukiman dan Pengembangan Wilayah, dengan anggota yaitu Menteri Dalam Negeri, Menteri Keuangan, Menteri Negara Pekerjaan Umum, Kepala Badan Perencanaan Pembangunan Nasional, Kepala Badan Pertanahan Nasional dan Kepala Badan Kesejahteraan Sosial Nasional.

Hingga saat ini, ketersediaan rumah bagi masyarakat berpenghasilan rendah masih sangat minim. Ledakan jumlah penduduk dan arus urbanisasi yang tinggi tidak diiringi dengan kesigapan Pemerintah untuk menyiapkan perumahan dan kawasan pemukiman yang layak. BPK4N dapat memberikan kontribusi dalam penyelenggaraan bank tanah, tepatnya pada proses pembangunan rumah terjangkau bagi masyarakat berpenghasilan rendah yang merupakan salah satu tujuan dari pembentukan bank tanah. Penyediaan rumah terjangkau bagi masyarakat berpenghasilan rendah merupakan salah satu upaya untuk mewujudkan kesejahteraan bagi seluruh rakyat Indonesia.

\section{Badan Koordinasi Penataan Ruang Nasional (BKPRN)}

Penataan ruang adalah suatu sistem perencanaan tata ruang, pemanfaatan ruang, dan pengendalian pemanfaatan ruang. Pasal 1 Keputusan Presiden No. 4 Tahun 2009 tentang Badan Koordinasi Penataan Ruang Nasional menyebutkan bahwa BKPRN terdiri dari: (1) Menteri Perekonomian; (2) Menteri Pekerjaan Umum; (3) Menteri Negara Perencanaan Pembangunan Nasional/ Kepala Badan Perencanaan Pembangunan Nasional; (4) Menteri Pertahanan; (5) Menteri Energi dan Sumber Daya Mineral; (6) Menteri Perindustrian; (7) Menteri Pertanian; (8) Menteri Kehutanan; (9) Menteri Perhubungan; ( 10) Menteri Kelautan dan Perikanan; (11) Menteri Negara Lingkungan Hidup; (12) Kepala Badan Pertanahan Nasional; dan (13) Wakil Sekretaris Kabinet.

Pada dasarnya, rencana tata ruang merupakan suatu bentuk intervensi negara yang dilakukan agar terwujud alokasi ruang yang nyaman, produktif, dan berkelanjutan dalam rangka 
meningkatkan kesejahteraan masyarakat. Manfaat dari BKPRN dalam penyelenggaraan bank tanah dapat ditemukan dalam (1) sektor infrastruktur, (2) sektor pelestarian lingkungan dan bencana, (3) sektor perumahan dan perkembangan desa.

Dari berbagai uraian di atas, maka dapat disimpulkan bahwa bank tanah merupakan suatu badan kerja sama kelembagaan antar sektor. Negara melalui Pemerintah dapat dilibatkan dalam pembentukan dan pelaksanaan bank tanah. Bank tanah yang paling tepat untuk dibentuk dalam rangka mewujudkan pengelolaan aset tanah negara yang berkeadilan di Indonesia adalah bank tanah berjenis publik. Tujuan utama pembentukan bank tanah publik yang dimaksud adalah non-profit oriented, sehingga bisa berbentuk lembaga negara, atau badan layanan, atau satuan kerja dari suatu kementerian/ departemen, baik di tingkat pusat maupun daerah, mengingat pemerintahan di Indonesia telah terdesentralisasi melalui otonomi daerah.

Penerapan konsep bank tanah di Indonesia harus didukung oleh sumber daya yang memadai untuk meminimalisir biaya pengumpulan dan pengelolaan tanah, karena banyaknya sumber objek tanah yang dapat menjadi sasaran utama bank tanah. Penunjang lain yang mendukung terwujudnya bank tanah dalam sistem hukum agraria Indonesia adalah berbagai regulasi pertanahan di Indonesia. Regulasi pertanahan harus mampu memberikan celah bagi kehadiran bank tanah. Selain itu, keberadaan badan koordinasi nasional yang terintegrasi seperti BPN, BKP4N, dan BKPRN, yang kesemuanya berkaitan erat dengan praktik bank tanah di Indonesia harus memberikan kontribusi dalam penyelenggaraan bank tanah.

\section{Penutup}

Penerapan konsep bank tanah dalam pengelolaan aset tanah negara dirasa dapat mewujudkan keadilan sosial (al-'Adalah alIjtima'iyyah) bagi seluruh rakyat Indonesia. Landasan hukum penerapan konsep bank tanah dapat ditemukan dalam sistem hukum agraria nasional, yakni HMN sebagaimana diatur dalam Pasal 33 Ayat (3) UUD NRI 1945 yang implementasinya dijabarkan lebih lanjut dalam Pasal 2 Ayat (2) UUPA. Dengan adanya landasan konstitusional tersebut, maka Pemerintah dapat mengadakan 
kegiatan bank tanah dengan membentuk suatu lembaga bank tanah berjenis publik. Penyelenggaraan bank tanah harus dilakukan secara independen dengan tetap mengacu pada hukum positif dan kebijakan pertanahan di Indonesia. Kebijakan pertanahan yang dimaksud menurut konstitusi nasional adalah mencakup pengaturan berbagai aspek pertanahan yang telah termuat dalam UUPA dan piranti strategis lain, di antaranya adalah aspek hukum, aspek tata ruang, dan aspek pajak. Selain ketiga aspek tersebut, juga terdapat aspekaspek lain, yaitu: aspek pembaruan agraria, aspek penataan ruang, aspek penanganan tanah terlantar, dan aspek kerja sama kelembagaan antar sektor-sektor pembangunan.

\section{Daftar Pustaka}

\section{Buku}

Alexander, Frank S. Land Banking as Metropolitan Policy (Blueprint for American Prosperity). USA: Metropolitan Policy Program at Brookings, 2008.

Hutagalung, Arie Sukanti dan Markus Gunawan. Kewenangan Pemerintah di Bidang Pertanahan. Jakarta: Raja Grafindo Persada, 2008.

Kementerian Perencanaan Pembangunan Nasional/ Badan Perencanaan Pembangunan Nasional. Buku Pegangan Perencanaan Pembangunan Daerah 2014 - Memantapkan Perekonomian Nasional Bagi Peningkatan Kesejahteraan Rakyat yang Berkeadilan. Jakarta: Kementerian Perencanaan Pembangunan Nasional/ Badan Perencanaan Pembangunan Nasional, 2013.

Limbong, Bernhard. Bank Tanah. Jakarta: Margaretha Pustaka, 2013.

Murad, Rusmadi. Administrasi Pertanahan. Bandung: Mandar Maju, 1997.

Qutb, Sayyid. Keadilan Sosial dalam Islam. Bandung: Pustaka, 1984.

Sumarjdono, Maria S.W. Kebijakan Pertanahan antara Regulasi dan Implementasi. Jakarta: Kompas Gramedia, 2001.

Warasih, Emsi. Pranata Hukum Sebuah Telaah Sosiologis, Semarang: PT. Suryandaru Utama, 2005.

\section{Artikel}


Ganindha, Ranitya. “Urgensi Pembentukan Kelembagaan Bank Tanah Sebagai Alternatif Penyediaan Tanah Bagi Masyarakat Untuk Kepentingan Umum". Jurnal Arena Hukum, Volume 09, No. 3 (Desember, 2016).

Milicevic, Dragana. "Review of Existing Land Funds in European Countries". Journal of Geonauka, Volume 2, No. 1 (Maret, 2014).

Ridwan. "Management of Abandoned Land in the Perspective of Islamic Law and National Law of Land". Jurnal Al-Ihkam, Volume 11, No. 1 (Juni, 2016).

Schwarz, Laura. "The Neighborhood Stabilization Program: Land Banking and Rental Housing as Opportunities for Innovation". Journal of Affordable Housing \& Community Development Law, Volume 19 No. 1 (Fall, 2009).

\section{Naskah Internet}

Jack Damen, "Land Banking in the Netherlands in the Context of Land Consolidation", 07 March 2004: http://www.fao.org/fileadmin/user_upload/Europe/docum ents/Events_2004/Land2004/Netherlands_paper.pdf (diakses tanggal 05 Mei 2017)

Sungkana, "Mengenal Bank Tanah/ Land Banking Sebagai Alternatif Manajemen Pertanahan", 05 Agustus 2015: https://www.djkn.kemenkeu.go.id/2013/artikel/mengenalbank-tanahland-banking-sebagai-alternatif-manajemenpertanahan (diakses tanggal 15 Mei 2017)

\section{Peraturan Perundang-undangan}

Undang-Undang Dasar Negara Republik Indonesia Tahun 1945.

Ketetapan MPR RI No. IX/MPR/2001 tentang Pembaruan Agraria dan Pengelolaan Sumber Daya Alam.

Undang-Undang No. 5 Tahun 1960 tentang Peraturan Dasar PokokPokok Agraria.

Undang-Undang No. 26 Tahun 2007 tentang Penataan Ruang.

Peraturan Pemerintah No. 11 Tahun 2010 tentang Penertiban dan Pendayagunaan Tanah Terlantar.

Peraturan Pemerintah No. 74 Tahun 2012 tentang Perubahan Atas Peraturan Pemerintah No. 23 Tahun 2005 tentang Pengelolaan Keuangan Badan Layanan Umum 
Peraturan Presiden No. 63 Tahun 2013 tentang Badan Pertanahan Nasional Republik Indonesia.

Peraturan Presiden No. 71 Tahun 2012 tentang Penyelenggaraan Pengadaan Tanah Bagi Pembangunan Untuk Kepentingan Umum

Keputusan Presiden No. 63 Tahun 2000 tentang Badan Kebijaksanaan dan Pengendalian Pembangunan Perumahan dan Pemukiman Nasional.

Keputusan Presiden No. 4 Tahun 2009 tentang Badan Koordinasi Penataan Ruang Nasional.

Keputusan Presiden No. 34 Tahun 2003 tentang Kebijakan Nasional di Bidang Pertanahan.

Putusan Mahkamah Konstitusi No. Perkara 001-021-022/PUU-1/2003, dibacakan dalam Persidangan Terbuka pada 15 Desember 2004, Berita Negara Republik Indonesia No. 102 Tahun 2004, 21 Desember 2004. 